\title{
GENETIC AND PHENOTYPIC MARKERS FOR SUCCESSFUL ATHLETIC PERFORMANCE FORECAST
}

\author{
Associate Professor, PhD V.V. Marinich \\ Polesski State University, Pinsk, Belarus
}

\begin{abstract}
In the modern research and practical provisions for the children's and adolescent sports, due emphasis will be made on a timely detection of the physical activity limiting factors and prudent initiatives to remove or mitigate these factors with the relevant correction tools being applied to attain the highest competitive performance standards with no detriment for the athlete's health.

Based on the study of the 5HTT gene polymorphisms in junior football and ice hockey players, about $25 \%$ and $20 \%$ of the football and ice hockey players, respectively, were diagnosed with the unfavourable genetic type predisposed to indirect aggression that may be of negative effect on their training and competitive activities.

The functional deviations identified by the study dictate the need in a reasonable pharmacological intervention to optimize the metabolic processes in the CNS and VNS and help maintain the high physical and mental workability rates.
\end{abstract}

Keywords: genetic markers, predisposition to sport. 


\section{Background}

As things now stand in modern sports, there is a high demand for integrated diagnostic surveys of highly skilled adolescent athletes to obtain dynamic profiles of the competitive process efficiency, design individual training plans and pharmacological support programs and make the training process performance forecasts [7]. At the same time, the training process optimization problem is always ranked among the top priorities and it may be solved only based on integrated medical and biological test data. It is the integrated approach that makes it possible to trace interrelations of the physiological systems in the process of body adaptation to physical loads [9].

Regular physical loads and mental stresses inherent in any athletic career are known to trigger changes in the serotonin transfer process, whilst it is the administration of agents inhibiting or mitigating the growth of serotonin concentration (5HT) in the CNS that helps improve working capacity in the athletic training process and delay fatigue effects $[1,9,10]$.

It is the contribution of the serotonin system in the central fatigue development processes under physical loads and mental stresses that makes the issues of individual specifics of the serotonin and dopamine system functionality so important both in the theoretical and practical aspects $[3,6,9,12]$.

A variety of physical practices and efficient pharmacological support give the means to step up the physical working capacity rates and speed up the rehabilitation processes when athletes are exposed to extreme loads $[4,5,7]$.

In a variety of the physical working capacity limiting factors, we would underline the following major ones: anaerobic and aerobic bio-energy resources of the athlete; neuromuscular (muscular strength and routine performance technique determining) abilities; and the psychological (individual motivation and competitive tactics determining) qualities. Of special importance for the modern athletic performance analysis are also genetic factors [1, 3-5].

It is a matter of common knowledge today that high-intensity activities in the sport disciplines falling beyond the individual genetic predisposition range may result in at least special work capacity limitations followed by downfalls in the individual competitive performance standards $[2,6,7,11]$. We believe that the modern sport selection and vocational orientation process will be designed with due consideration both for the individual genetic predispositions to different physical activities and the individual body homeostasismaintenance abilities and the de-adaptation/ pathology-propagation preventing resources. In 
this context, the reasonable training load design and management based on the genetic predispositions at the early stage of a sport career and due training process corrections at the later stages tailored to the individual traits and needs of the athlete - will be given a due priority by modern sport science $[6,7]$.

Objective of the study was to identify, based on integrated monitoring of the highly-skilled junior athletes' fitness state, influences of the ACE/ 5HTT gene polymorphisms and offer an education/ training process correction program covering every process stage.

Methods and organisation of the research. We used a full-colour visual-motor response analyzer Psycho-Test system in the study. To ensure the diagnostics process being highly accurate, the average response time to a few dozens of impulses was calculated, with the error rate being assumed as indicative of the subject's attention stability. In case of high attention stability, the subject was generally capable of keeping the attention duly concentrated through the whole test time making virtually no errors in the test process. Simple visual-motor response (SVMR) test data were used to rate the CNS qualities and the current functional status and calculate the athletic working capacity rates.

Buccal epithelium was sampled as a biological material for the tests. The tests were designed to identify L/S polymorphisms of the 5HTT gene that were assumed to be characteristic of the individual predisposition to depression, stability under mental stresses and the central fatigue propagation process under high physical loads and mental stresses - and thereby identify and prove benefits of these tests and analysis for the sport selection process.

The amplified products were electrophoresed to identify their size. LL genotype is determined by fragments composed of $311 \mathrm{bp}$ (base pairs); L/S genotype - by two fragments of $267 \mathrm{bp}$ and $311 \mathrm{bp}$; and S/S genotype by a fragment of $267 \mathrm{bp}$.

ACE gene encodes the amino-acid sequence of the angiotensin-transforming ferment (ATF) that acts as an important physiological regulator of blood pressure and water-salt metabolism. ACE is the most well studied gene in the physical activity genetics. I-allele (287-bp alu repeat sequence) is deemed to determine the individual predisposition to the endurance- and hypoxia-tolerance-intensive sports (with high-altitude trainings) that require high strength grow rates in response to physical loads. D-allele is associated with the predisposition to dynamic and explosive strength growth and muscle mass increase.

To identify sizes of the amplified products, we applied electrophoresis. I/I genotype is determined by fragments composed of 479 bp (base pairs); I/D genotype - by two fragments of $479 \mathrm{bp}$ and $192 \mathrm{bp}$; and D/D genotype - by a fragment of $192 \mathrm{bp}$. 
Subject to the study were 180 junior (12-15 years old) athletes of the football and hockey academies based in Moscow city - who were tested in pre-season and regular season prior to and after the games.

Study results and discussion. The genetic analysis of the junior football and hockey players made it possible to trace a few distribution regularities for the ACE_Alu I/D_rs4646994, 5HTT_L/S gene polymorphisms (see Table 1 hereunder).

A group of subjects under the study were diagnosed with D-allele dominating in the angiotensin-transforming ferment (ATF) gene that is associated with a predisposition to the speed- and strength-intensive sports where high anaerobic work capacity rates and choleric temperaments are preferable. It should be noted that this attribute was found more expressed in the subject hockey players than in the football players.

Having analysed polymorphisms of the 5HTT gene of the serotonin system that was used as a marker of individual stability under physical loads and mental stresses, we found that the subject junior athletes mostly belonged to the heterozygote (LS) type or were carriers of the mutant S-allele, with the subject hockey players group showing the highest proportion of the S-allele carriers. This genotype is known to have lower concentrations of the serotonin transporter agent. The carriers are known to be inclined to indirect aggression, moderate negativism and irritation; and under intensive physical loads and mental stresses such athletes are normally tested with relatively higher simple/ complex response rates albeit lower mental stability rates. They may also have good accomplishments in the speed- and strength-intensive skills training process conditional on due corrections being made to prevent monotony in the training process. 
Table 1. Proportions of the gene polymorphisms in the subject athletes

\begin{tabular}{|c|c|c|c|c|c|}
\hline Gene & \multicolumn{5}{|c|}{ Genotype proportions, $\%$} \\
\hline \multicolumn{6}{|c|}{ Football players, $n=140$} \\
\hline \multirow[t]{2}{*}{ 5HTT_L/S } & \multicolumn{2}{|l|}{$\mathbf{L L}$} & \multicolumn{2}{|l|}{$\mathbf{L S}$} & SS \\
\hline & \multicolumn{2}{|c|}{$20 \%$} & \multicolumn{2}{|l|}{$55 \%$} & $25 \%$ \\
\hline \multirow[t]{2}{*}{ ACE_Alu I/D } & \multicolumn{2}{|l|}{ DD } & \multicolumn{2}{|l|}{ ID } & II \\
\hline & \multicolumn{2}{|c|}{$35 \%$} & \multicolumn{2}{|l|}{$45 \%$} & $20 \%$ \\
\hline \multicolumn{6}{|c|}{ Hockey players, $n=40$} \\
\hline \multirow[t]{2}{*}{ 5HTT_L/S } & \multicolumn{2}{|l|}{$\mathbf{L L}$} & \multicolumn{2}{|l|}{$\mathbf{L S}$} & $\mathbf{S S}$ \\
\hline & \multicolumn{2}{|c|}{$10 \%$} & \multicolumn{2}{|l|}{$65 \%$} & $25 \%$ \\
\hline \multirow[t]{2}{*}{ ACE_Alu I/D } & \multicolumn{2}{|l|}{ DD } & \multicolumn{2}{|l|}{ ID } & II \\
\hline & \multicolumn{2}{|c|}{$65 \%$} & \multicolumn{2}{|l|}{$25 \%$} & $10 \%$ \\
\hline \multicolumn{6}{|c|}{ Proportions of endurance-specific alleles } \\
\hline & \multirow[t]{2}{*}{$\mathrm{n}$} & \multicolumn{4}{|l|}{ Alleles } \\
\hline & & \multicolumn{2}{|l|}{ I (ACE) } & \multicolumn{2}{|l|}{ L (5HTT) } \\
\hline Football players & 20 & $42,5 \%$ & & $47,5 \%$ & \\
\hline Hockey players & 20 & $22,5 \%$ & & $42,5 \%$ & \\
\hline \multicolumn{6}{|c|}{ Proportions of speed- and strength-specific alleles } \\
\hline & \multirow[t]{2}{*}{$\mathrm{n}$} & \multicolumn{4}{|l|}{ Alleles } \\
\hline & & \multicolumn{2}{|l|}{$\mathrm{D}(\mathrm{ACE})$} & \multicolumn{2}{|c|}{ S (5HTT) } \\
\hline Football players & 20 & $57,5 \%$ & & $52,5 \%$ & \\
\hline Hockey players & 20 & $77,5 \%$ & & $57,5 \%$ & \\
\hline
\end{tabular}

Most of the subjects were qualified as well predisposed to speed-, strength- and enduranceintensive skills being developed and demonstrated in their vocational game roles in the team sports. Reasonable corrective actions to prevent monotony in the training process plus current psycho-physiological diagnostics of the homozygote SS carriers will help counter the central fatigue propagation process by due corrective actions to prevent the serotonin-deficiency effects that may contribute to the physical work capacity limitations.

The study data and analysis are indicative of multiple gene polymorphisms being involved in athletic performance process. Therefore, the molecular-genetic diagnostics methods in sports 
are undoubtedly promising for the tests with the relevant markers being used, in addition to the applicable phenotypic tests.

In the SVMR test data of the junior hockey players, the following regularities may be noted: dominance of low/ medium response rates, with the proportion of the high response rates being under $8 \%$ of the sample. The error rates in the SVMR tests were under the critical levels that may be indicative of the signal-CNS transmittance speeds falling as a result of fatigue. However, the attention stability and total work capacity rating tests showed the rates falling down to the lower limit of the normal range in $75 \%$ of the football players tested. Furthermore, $25 \%$ of the football players were tested with notable work capacity falls, the finding being attributable to the variability limitations of the visual response test method accuracy.

The error rates in the SVMR tests of the junior hockey group were the following: $65 \%$ of the subjects showed low error rates under 5 (wrong key presses); $25 \%$ of the subjects were tested with medium error rates of 5-10 wrong key presses; and 10\% with high error rates of 10 plus wrong key presses.

By the dominant type of the higher nervous activity, the football group was rated as follows: $75 \%$ of the junior football players were rated with a mobile type; and the remaining quarter of the group - with an intermediate (inert to mobile) dominant high nervous activity type. The hockey players were tested with a somewhat higher (trend-level) proportion of the mobile type of the dominant high nervous activity (see Figure 1).

In analysis of the error rates in the SVMR and choice tests of the junior hockey group, 50\% of the subjects showed the error rates under 10 (wrong key presses); 27\% made 11-20 errors; $15 \%$ of the group made $22-30$ errors; and $8 \%$ gave 31 to 50 wrong responses. 


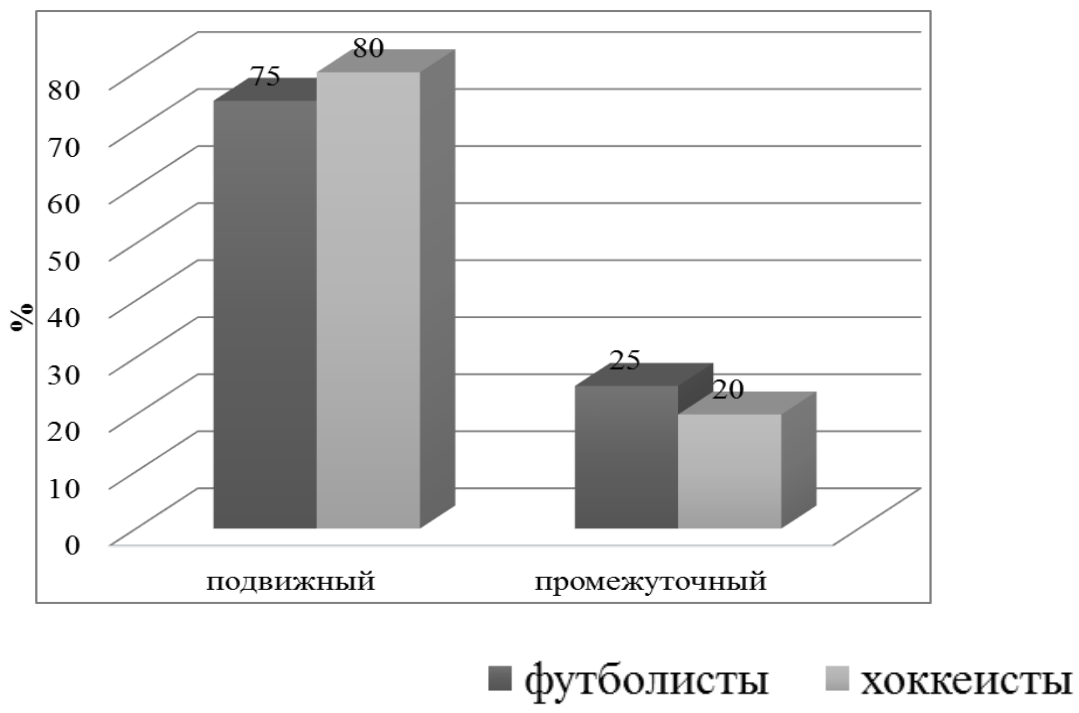

Figure 1. High nervous activity rating tests of the junior athletes

Mobile Intermediate

Football group Hockey group

Tests of the junior athletes of both of the groups in the pre-season showed their physical and mental resources being mobilized at optimal levels (see Figure 2).

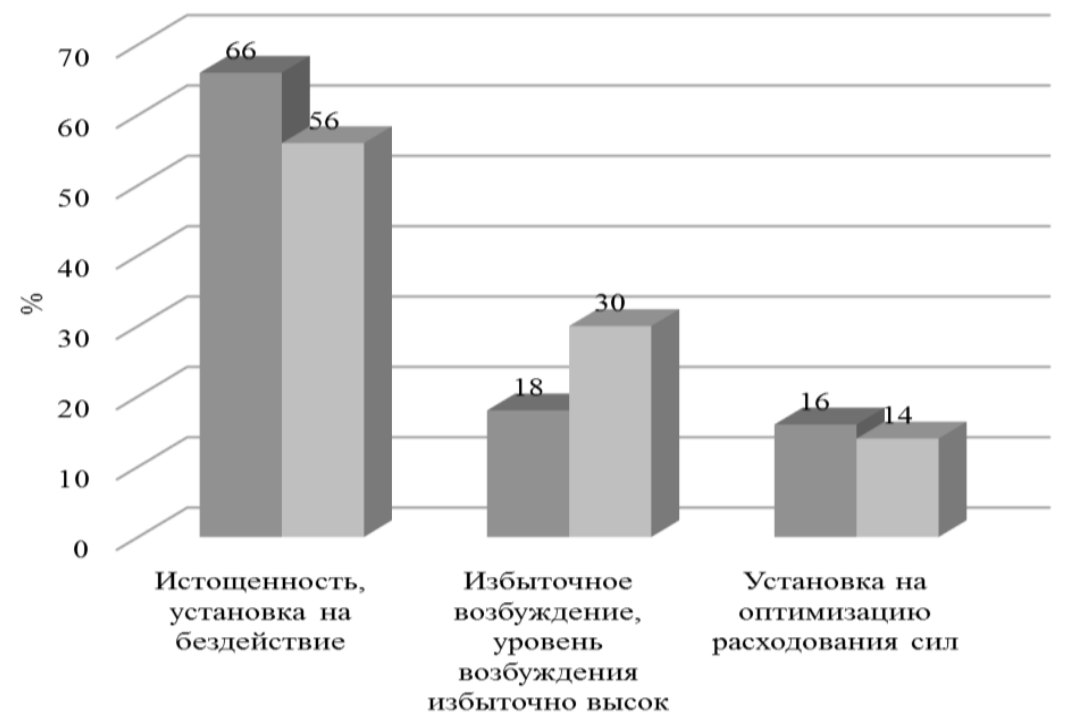

\section{футболисты $\square$ хоккеисты}

Figure 2. Physical and mental resource mobilization rates of the junior athletes

Exhaustion, inactivity-focused mindset Excessive activity, too high excitation rate Energyefficient mindset

Football group Hockey group 
The SVMR and choice tests of both of the groups showed significant $(\mathrm{p}<0.05)$ differences in the average response rates, decision-making time rates and the CNS functionality rates. Of special interest in the tests were the significant differences in the estimated decision-making time (DMT) rates. The hockey players were tested with the lower DMT rates, the finding being attributable to the generally higher requirements to the analytical capacity of players in the decision-making process as dictated by the sport discipline specifics (see Table 2 hereunder).

Table 2. The simple and complex visual-motor response test rates and heart rate variability indices of the subject athletes

\begin{tabular}{|c|c|c|c|}
\hline \multicolumn{2}{|l|}{ Rates } & $\begin{array}{l}\text { Football players, } \\
n=60\end{array}$ & $\begin{array}{l}\text { Hockey players, } \\
n=35\end{array}$ \\
\hline \multirow{3}{*}{ SVMR } & Average response time, $\mathrm{ms}$ & $214,86 \pm 15,23$ & $229,12 \pm 21,45^{*}$ \\
\hline & Functionality rate, conv. units & $4,65 \pm 0,44^{*}$ & $4,72 \pm 0,41$ \\
\hline & $\begin{array}{l}\text { Functional capacity rate, conv. } \\
\text { units }\end{array}$ & $3,71 \pm 0,63$ & $3,58 \pm 0,66$ \\
\hline $\begin{array}{l}\text { Complex } \\
\text { VMR }\end{array}$ & Average response time, $\mathrm{ms}$ & $313,1 \pm 33,16$ & $310,16 \pm 26,14$ \\
\hline \multicolumn{2}{|c|}{ Decision-making time, $\mathrm{ms}$} & $98,24 \pm 19,2$ & $81,04 \pm 11,6^{*}$ \\
\hline \multicolumn{2}{|c|}{$\mathrm{TP}, \mathrm{ms}^{2} / \mathrm{Hz}$} & $4746(1125-15615)$ & $2722(632-4263)^{*}$ \\
\hline \multicolumn{2}{|l|}{$\mathrm{LF} / \mathrm{HF}$} & $9,0(2,8-28,3)$ & $6,9(2,0-15,5)$ \\
\hline \multicolumn{2}{|l|}{$\mathrm{LF}, \%$} & $54,1(33,7-67,0)$ & $47,9(30,0-61,1)$ \\
\hline \multicolumn{2}{|l|}{ HF, \% } & $5,7(1,7-14,9)$ & $7,5(2,8-17,9)$ \\
\hline
\end{tabular}

We used a few mental condition regulators in the study to level down the excessive mental responses to the challenging moments in the process that are particularly expressed in team sports.

General analysis of the study data showed the need in the relevant principal corrections to the test methods to step up the testing process efficiency (see Figure 3).

\section{Conclusion}

The junior athletes were tested with notable variations of the visual-motor response rates with the technical error rates of the core motor actions being on the rise with the growing fatigue; 
and the total working capacity rates and vegetative balance rates were found to correlate with the high nervous activity types.

Real-time test data of that kind will give the means to efficiently control and correct the training process as dictated by the tested specific visual-motor response rates, decisionmaking time rates and the emotional performance rates of the junior athletes.

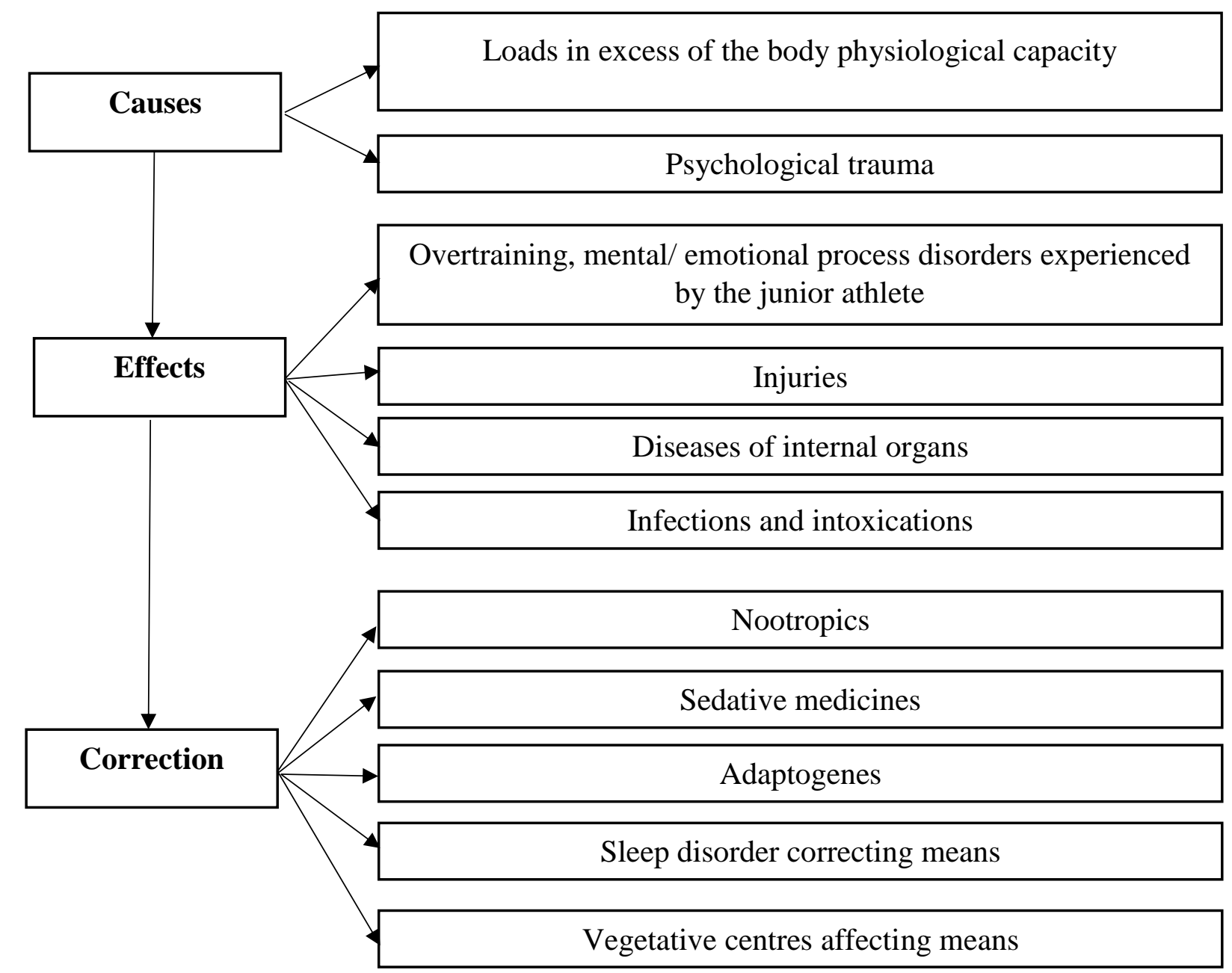

Figure 3. Central/ peripheral/ vegetative nervous systems: depression factor analysis and correction model

Based on the study of the 5HTT gene polymorphisms in 80 junior football and hockey players, about $25 \%$ and $20 \%$ of the football and hockey players, respectively, were diagnosed with the unfavourable genetic type predisposed to indirect aggression that may be of negative effect on their training and competitive activity.

The functional deviations identified in the study dictate the need in a reasonable pharmacological intervention to optimize the metabolic processes in the CNS and VNS and help maintain high physical and mental working capacity rates. 


\section{References}

1. Akhmetov I.I. Molekulyarnaya genetika sporta: monografiya (Molecular sport genetics: monograph) / I.I. Akhmetov. - Moscow: Sovetskiy sport, 2009. - 268 p.

2. Guba V.P. Detskaya odarennost' $i$ talant: integral'naya otsenka, analiz diagnosticheskikh metodov (Children's giftedness and talent: integrated assessment, analysis of diagnostic methods) / V.P. Guba, A.V. Solodnikov // Izvestiya Rossiyskoy akademii obrazovaniya.-Moscow, 2015.-№3(35). - P.71-78.

3. Guba V.P. Integral'naya otsenka funktsional'nogo sostoyaniya sistemy vneshnego dykhaniya kvalifitsirovannykh sportsmenov, spetsializiruyushchikhsya $v$ mini-futbole (Integrated assessment of functional state of external respiration system of skilled futsal players) / V.P. Guba, S.L. Skorovich, V.V. Marinich // Teoriya i praktika fiz. kultury. -2013. - № 10. - P. 21-25.

4. Guba V.P. Kompleksny podkhod $v$ otsenke funktsional'nogo sostoyaniya professional'nykh sportsmenov (Integrated approach in assessment of functional state of professional athletes) / V.P. Guba, V.V. Marinich // Vestnik sportivnoy nauki (Journal of sport science). - 2013. - № 6. - P. 47-52.

5. Guba V.P. Osnovy sportivnoy podgotovki: monografiya (Fundamentals of sport training: Monograph) / V.P. Guba. - Moscow: Sovetskiy sport, 2012. - 360 p.

6. Guba V.P. Sovremennye realii integral'nykh osobennostey effektivnogo vypolneniya sorevnovatel'noy nagruzki (Modern realities of integral features of effective competition performance) / V.P. Guba // Teoriya i praktika fiz. kultury. - 2015. - № 11. - P. 76-78.

7. Guba V.P. Talant $i$ kriticheskie tochki genotipa (Talent and critical points of genotype) / V.P. Guba. - Moscow: Nauka i zhizn', 2013. - P. 33.

8. Kulinenkov O.S. Farmakologicheskaya pomoshch sportsmenu: korrektsiya faktorov, limitiruyushchikh sportivny rezul'tat (Pharmacological support in sport: correction of factors limiting athletic performance) / O.S. Kulinenkov. - Moscow: Sovetskiy sport, 2007. $-146 \mathrm{p}$.

9. Makarova G.A. Farmakologicheskoe obespechenie $v$ sisteme podgotovki sportsmenov (Pharmacological support of athletic training system) / G.A. Makarova. Moscow: Sovetskiy sport, 2003. -160 p.

10. Psikhodiagnostika funktsional'nykh sostoyaniy cheloveka (Psychodiagnostics of functional states in man) / Ed. by A.B. Leonov. - Moscow, 1984. - 469 p.

11. Seyfulla R.D. Sportivnaya farmakologiya: spravochnik (Sport pharmacology: reference book) / R.D. Seyfulla. - Moscow: SportFarma, 1999. - 128 p.

12. Charykova I.A. Psikhofiziologicheskie kriterii peretrenirovannosti u sportsmenov (Psychophysiological criteria of overtraining in athletes) / I.A. Charykova, E.A. Statsenko // Voprosy kurortologii, fizioterapii i lechebnoy fizkul'tury. - 2010. - № 2. - P. 50-53.

\section{Corresponding author: vital4714@yandex.ru}

